\title{
HIGH-VOLTAGE MODULATOR OF THE LINAC INJECTOR WITH VOLTAGE PULSE STABILIZATION
}

\author{
R.A. Anokhin, S.N. Dubniuk, N.I. Gaponenko, A.P. Kobets, A.I. Kravchenko, \\ O.V. Manuilenko, V.N. Reshetnikov, A.S. Shevchenko, V.A. Soshenko, V.G. Svichenskiy, \\ B.V. Zajtsev, A.V. Zabotin, V.G. Zhuravlyov, A.V. Zhuravlyov \\ National Science Center “Kharkiv Institute of Physics and Technology”, Kharkiv, Ukraine \\ E-mail: zajtsev@kipt.kharkov.ua
}

The high-voltage pulse modulator based on the modern semiconductor elements is described. The modulator is intended for use in the power supply system of LINAC helium ions injector and has the ability to smoothly adjust the amplitude $(110 \ldots 150 \mathrm{kV})$ and the pulse duration $(0.5 \ldots 1 \mathrm{~ms})$. The use of a pulse-to-peak stabilization scheme, made on the basis of a parametric stabilizer with parallel switching of the load, made it possible to increase the accelerated current at the accelerator output by 2 times.

PACS: 29.20.-c

\section{INTRODUCTION}

Ion beams are widely used in science and industry: from high-energy and nuclear physics, material science and inertial confinement fusion to medicine and track membranes production [1 - 10]. The new pre-stripping section PSS-4 of the linear accelerator of multiply charged ions is designed to study the changes in properties of nuclear power plants structural materials during their operation. It is possible to simulate the processes, occurring in materials during radiation exposure in reactor cores under stationary and transient operating conditions, using accelerated charged particles. Such studies include the study of the specific features of changes in the mechanical properties and dimensional stability of materials when irradiated by high-energy ions [2, 3]. Modeling of processes occurring in materials located in the radiation field of the reactor core requires long irradiation sessions and can reach several tens of hours, which imposes its own requirements on the reliability of operation of both the equipment complex and the accelerator as a whole [6 - 10]. To reduce the test duration, it is necessary to increase the flux density of accelerated charged particles, which primarily depends on the stability of the power supply systems of the injector $[8,13$ - 15], in particular, the high voltage pulse modulator. This paper addresses issues related to the development of modulators of stabilized $(0.5 \%)$ high voltage pulses (up to $150 \mathrm{kV}$ ) with regulation of the pulse duration $0.1 \ldots 1 \mathrm{~ms}$.

\section{INJECTOR MODULATOR}

In addition to high reliability and small dimensions, the modulator is required to increase the pulse repetition frequency, to suppress oscillations at the peak of the voltage pulse and to adjust the amplitude of the output voltage within $1 \ldots 10 \mathrm{kV}$. Since changes in the accelerating voltage leads to an increase in the velocity spread of the particles injected into the accelerator and, as a result, decrease in the output current of the accelerator, the stability of the output signal amplitude is of paramount importance.

Two types of modulator, in the course of the work, is made and tested. The first one is made on a double forming line (DFL) with LC links. Thyristors are used as a switching element of the modulator. To increase the permissible key voltage, ten series-connected thyristors were applied, which made it possible to increase the voltage on the key to $12 \mathrm{kV}$. A step-up transformer is connected to the output of the modulator. The electrical strength of a transformer is achieved by placing it in oil.

The disadvantage of this modulator type is a generated pulse fixed length. In addition it should be noted that in such devices the duration of the pulse fronts is determined by the delay time of the LC cell. Also, when the modulator loads mismatch with the DFL wave resistance, oscillations may occur at the pulse fronts. When conducting experiments on the PSS-4 injector and accelerator operation, this modulator provided the output pulse amplitude of $126 \mathrm{kV}$ for duration of $500 \mu \mathrm{s}$ and the frequency of $5 \mathrm{~Hz}$. Experiments have shown its reliability. Such modulators are widely used, therefore, show schematic diagrams here do not make sense. It is obvious that the reactive parameters of the transformer affect the shape of the voltage pulse on the injector. The oscillograms of the output pulse of this modulator type in comparison with the stabilized pulse are presented in [16 - 18]. In the process of upgrading the injector power supply system, a modulator was developed with a variable output signal duration, which allows changing the conditions for conducting physical experiments. Fig. 1 shows the block diagram of the modulator. It consists of submodulator, which forms a pulse duration $0.1 \ldots 0.7 \mathrm{~ms}$ and a high-voltage switch. The high-voltage switch commutes the rectifier to the output transformer of the modulator for a time determined by the duration of the output signal of the submodulator.

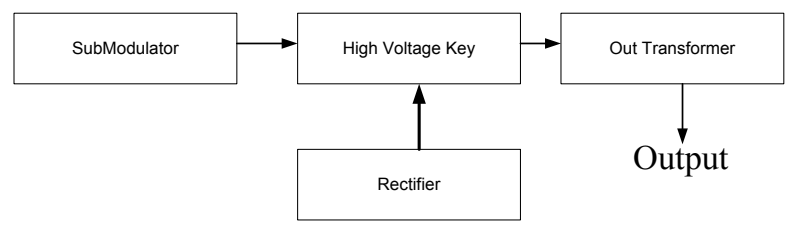

Fig. 1. The modulator circuit block based on a high-voltage switch

When a trigger signal arrives at its input, the submodulator generates a pulse of a given duration and voltage amplitude necessary to turn on the high-voltage switch. The submodulator circuit is shown in Fig. 2. On the transistor VT1 assembled amplifier, which receives a differentiated start signal. On the transistor VT2 as- 
sembled current generator, which charges the capacitor $\mathrm{C} 2$. When a start pulse arrives at the input of the submodulator, the transistor VT1 discharges capacitor C2. When the transistor is closed, the voltage on the capacitor starts to increase linearly with rate determined by the generator current. When the switching threshold of the amplifier limiter, assembled on transistors VT3-VT8, reached, the amplitude of the output signal switches from high potential to zero. To ensure high pulse current loads at the output of the submodulator, a composite emitter follower is installed on transistors VT7 and VT8. The submodulator has high noise immunity and allows changing the duration of the output signal over a wide range [19 - 21].

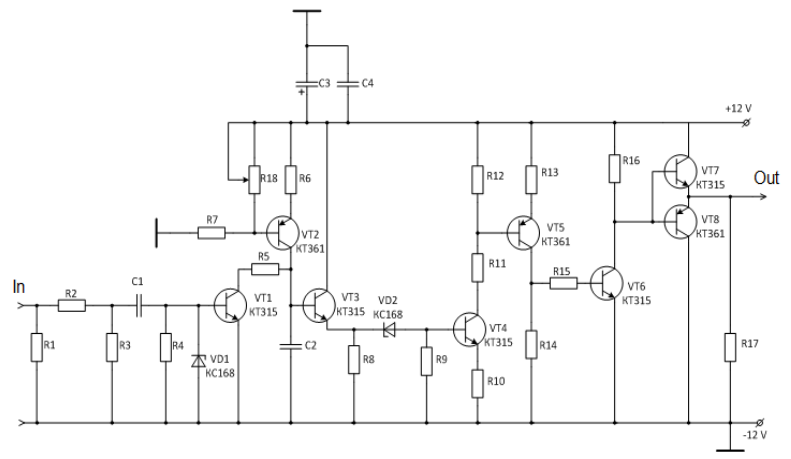

Fig. 2. Schematic diagram of the submodulator

Fig. 3 shows the diagram of the modulator highvoltage switch. It consists of ten field-effect transistor modules (IRG4PC40UD), connected in series, to increase the amplitude of the supply voltage. This key allows you to work with voltages up to $12 \mathrm{kV}$ and currents up to $30 \mathrm{~A}$. The key load is a pulse transformer with a transformation ratio $\mathrm{K}=20$.

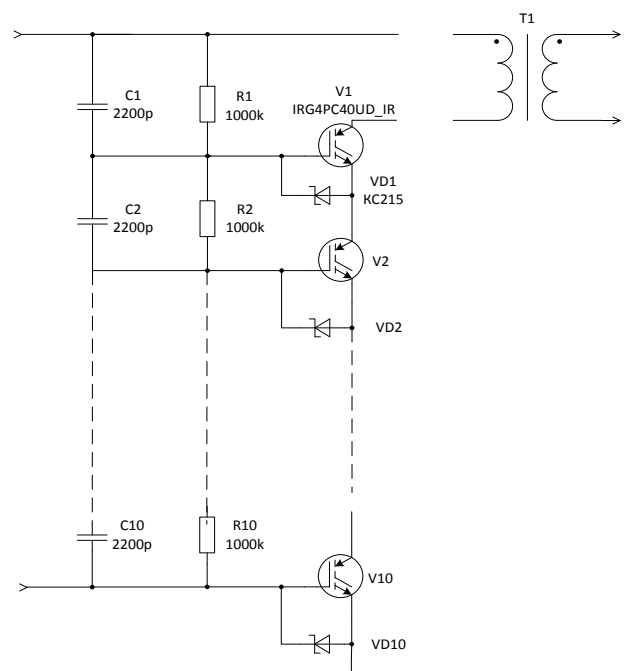

Fig. 3. High voltage switch circuit

In the initial state, the transistors are closed, and the voltage on the transistors collectors is distributed evenly. When a positive signal with amplitude $12 \mathrm{~V}$ arrives at the gate of transistor V10, that exceeds the threshold of opening of the transistor $(7 \mathrm{~V})$, it opens. The voltage across the resistors decreases sharply, leading to an avalanche-like opening of all transistors. The opening speed is affected by the capacitance value of the capacitors $\mathrm{C} 1-\mathrm{C} 10$, since it provides overcharging of the input capacitance of the transistors. Zener diodes VD1-VD10 limit the pulse voltages on the gates within acceptable limits, preventing the output transistors from failure. Checking its operation for the equivalent of the load allowed to provide the necessary voltages $(135 \mathrm{kV})$ and the pulse duration within $0.3 \ldots 1.2 \mathrm{~ms}$. The modulator also allows the use of a single output transformer to work with both modulators, increasing efficiency in eliminating potential malfunctions. Currently, the modulator is being tested for its entry into the accelerator equipment.

\section{STABILIZATION OF THE INJECTOR VOLTAGE}

The need to stabilize and adjust the voltage applied to the injector was justified above. Stabilizing voltages in excess of tens of kilovolts is fraught with difficulties, since circuit elements must withstand considerable voltages (tens of kilovolts) [6 - 10, 13 - 15].

The most widely known methods of voltage stabilization are due to the inclusion of the regulating element, either sequentially or in parallel with the load. However, both of these methods require the presence of regulatory elements that allow a high maximum allowable voltage. The choice of such elements is limited and is represented by electro vacuum devices. Their main disadvantages are high power dissipation (more than $200 \mathrm{~W}$ ) and the need to add additional nodes (bias voltage sources, rectifiers) to the circuit, which increases the dimensions of the equipment and reduces its reliability.

Currently semiconductor diodes Transient Voltage Suppressors have appeared. They are designed to protect semiconductor transistors from overvoltages caused by transients in power electronics. These diodes make it possible to dissipate the pulsed power of $1.5 \mathrm{~kW}$, with a limiting voltage of up to $400 \mathrm{~V}$. Their main difference from traditional zener diodes is the reduced capacitance of the $p-n$ junction, which ensures switching time in nanoseconds. The appearance of these elements made it possible to increase the voltage to hundreds of kilovolts due to their sequential switching on and to apply a simple parametric stabilizer scheme with parallel switching on of stabilizing elements.

Fig. 4 shows the stabilizer circuit. In it, the stabilizing element is made of $3001.5 \mathrm{KE} 400$ diodes in series, which made it possible to obtain a voltage on this chain of $120 \mathrm{kV}$.

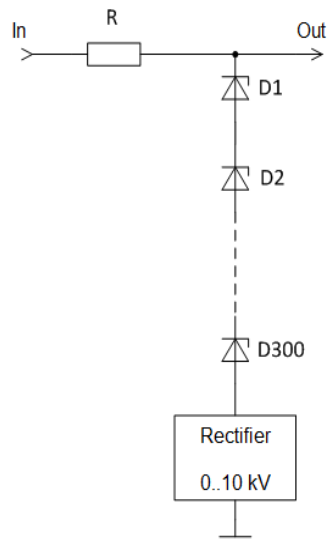

Fig. 4. Scheme of the voltage regulator of the power injector 
When a voltage pulse arrives at the stabilizer input from the modulator transformer, the voltage on the diodes is limited to the value determined by the voltage drop on the diodes and the output voltage of the rectifier connected in series with the diodes. Changing the polarity of the rectifier connection allows you to adjust the output voltage, both in the direction of its increase and decrease. Resistor $\mathrm{R}$ limits the current flowing through the diodes.

The oscillograms of the injector supply high-voltage pulses for variants a) and b) is showed in Fig. 5. Comparison of the shape of the initial a) and stabilized b) pulses clearly shows the effectiveness of the stabilization of high-voltage pulsed voltages. The measurement results showed that the voltage instability does not exceed $1.5 \%$.

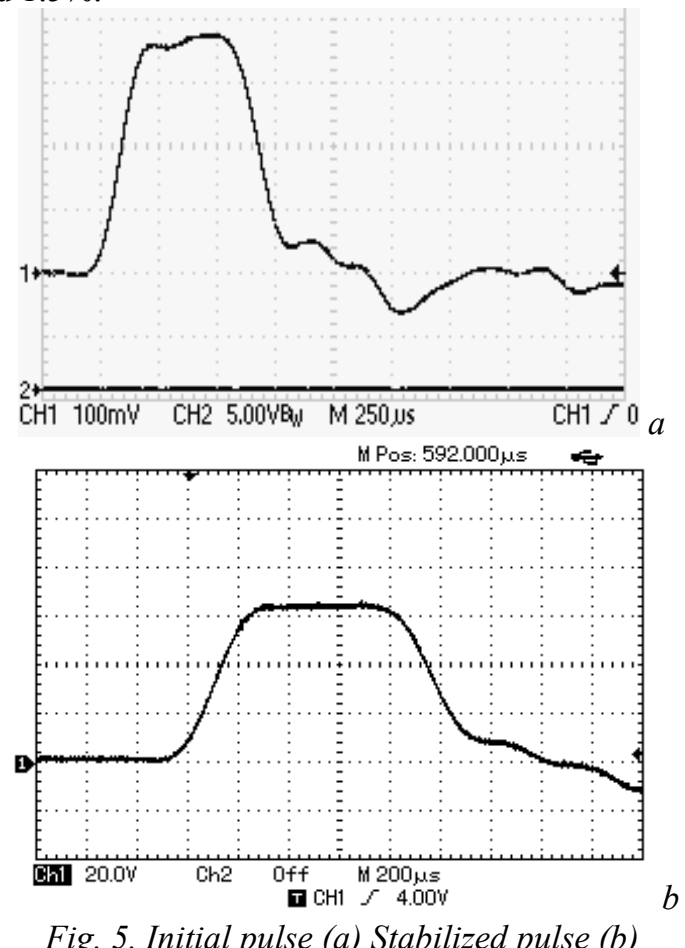

Fig. 6 shows the output transformer of the injector modulator (left) and the oil tank of a high-voltage stabilizer. This placement has reduced the length and number of wires under high voltage.

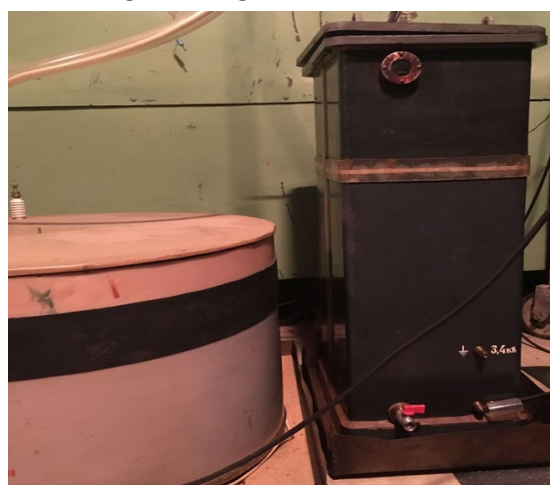

Fig. 6. Modulator output transformer and high voltage stabilizer

\section{CONCLUSIONS}

A stabilized high-voltage pulsed power source for the helium ion linear accelerator injector, consisting of a submodulator and a high-voltage switch loaded onto the output transformer, has been developed. A synchronized pulse generator was used as a submodulator, with controlled pulse duration $(0.1 \ldots 1 \mathrm{~ms})$. The stabilization voltage is $120 \mathrm{kV}$, with a possibility of adjusting $\pm 12 \mathrm{kV}$. Unevenness of the pulse top is within $0.5 \ldots 1 \%$. The source has a high stability of the generated signal under conditions of intense impulse noise. As a result of the introduction of stabilization of the amplitude of the pulsed power supply of the accelerator, the accelerator current has doubled.

\section{REFERENCES}

1. V.A. Bomko, A.M. Yegorov, B.V. Zaytsev, et al. Development of the MILAC complex for nuclear physical investigations // Problems of Atomic Science and Technology. Series "Nuclear Physics Investigations”. 2008, № 3, p. 100-104.

2. V.N. Voyevodin. Structural materials of nuclear power - challenge to 21 century // Problems of Atomic Science and Technology. Series "Physics of Radiation Effect and Radiation Materials Science”. 2007, № 2, p. 10-22.

3. I.M. Neklyudov. State and problems of nuclear power in Ukraine // Problems of Atomic Science and Technology. Series "Physics of Radiation Effect and Radiation Materials Science”. 2007, № 2, p. 3-9.

4. O.V. Bogdan, V.I. Karas', E.A. Kornilov, et al. 2.5dimensional numerical simulation of a high-current ion linear induction accelerator // Plasma Physics Reports. 2008, v. 34, № 8, p. 667-677.

5. O.V. Bogdan, V.I. Karas', E.A. Kornilov, et al. High current ion induction LINAC for heavy ion fusion: 2D3V numerical simulation // Problems of Atomic Science and Technology. Series "Plasma Physics". 2008, № 6, p. 110-114.

6. R.A. Anokhin, V.N. Voyevodin, S.N. Dubnyuk, et al. Methods and experimental results constructions materials irradiation of helium ions at the linear accelerator // Problems of Atomic Science and Technology. Series "Physics of Radiation Effect and Radiation Materials Science”. 2012, № 5, p. 123-130.

7. S.N. Dubniuk, B.V. Zajtsev. The linear accelerator for radiation structural materials // Problems of Atomic Science and Technology. Series "Nuclear Physics Investigations”. 2014, № 3, p. 172-176.

8. R.A. Anokhin, S.M. Dubniuk, B.V. Zajtsev, et al. Irradiation technique of constructional materials on the helium ions linac // Problems of Atomic Science and Technology. Series "Nuclear Physics Investigations”. 2016, № 3, p. 79-83.

9. S.M. Dubniuk, R.A. Anokhin, A.F. Dyachenko, et al. Radiation complex on the basis of helium ions linac // Problems of Atomic Science and Technology. Series "Plasma Electronics and New Methods of Acceleration”. 2018, № 4, p. 46-51.

10. R.A. Anokhin, S.M. Dubniuk, A.F. Dyachenko, et al. Beam and target parameters measurement system on helium ions linear accelerator // Problems of Atomic Science and Technology. Series "Plasma Electronics and New Methods of Acceleration". 2018, № 4, p. 30-35 
11. M.T. Bryk, A.F. Kobets, A. Kryshtal, et al. Investigation of porous structure in the PET films irradiated with Ar ions // Nuclear Instruments and Methods in Physics Research, B: Beam Interactions with Materials and Atoms. 2006, v. 251, № 2, p. 419-424.

12. V.A. Bomko, A.F. Burban, A.F. Kobets, et al. Initial stage of etching through pores in PET films irradiated by Ar ions // Nuclear Instruments and Methods in Physics Research, B: Beam Interactions with Materials and Atoms. 2008, v. 266, № 2, p. 256-261.

13. V.A. Bomko, B.V. Zajtsev, A.P. Kobets, et al. Heavy ions beams formation in an initial part of accelerating structures prestripping section the milac linear accelerator // Problems of Atomic Science and Technology. Series "Nuclear Physics Investigations”. 2012, № 4, p. 15-19.

14. A.G. Belikov, L.A. Bondarenko, Ye.V. Gussev et al. Investigation of beam extraction and formation in the ions injector // Problems of Atomic Science and Technology. Series "Nuclear Physics Investigations”. 2018, № 3, p. 63-67.
15. A.G. Belikov, L.A. Bondarenko,Ye.V. Gussev, et al. Transport and matching of the injecting beam // Problems of Atomic Science and Technology. Series "Nuclear Physics Investigations". 2018, № 3, p. 6872.

16. B.P. Murin, V.G. Kuhlman, L.G. Lomize, et al. Linear ion accelerators: in 2 volumes. Basic systems. M.: "Atomizdat", 1978, 320 p.

17. A.G. Sobolevsky. Pulse technique. M.: "Gosenergoizdat", 1958, $167 \mathrm{p}$.

18. S.S. Vdovin. Design of pulse transformers. L.: "Energoatomizdat", 1991, 208 p.

19. M. Brown. Power supply cookbook. Boston: "Newnes", 2001, 265 p.

20. M. Gottlieb. Power sources. Inverters, converters, linear and pulse stabilizers. M.: "Postmarket", 2002, $544 \mathrm{p}$.

21. R. Mack. Pulse power supplies. M.: "Dodeca", 2008, $271 \mathrm{p}$.

Article received 02.05.2019

\title{
ВЫСОКОВОЛЬТНЫЙ МОДУЛЯТОР ИНЖЕКТОРА ЛИНЕЙНОГО УСКОРИТЕЛЯ СО СТАБИЛИЗАЦИЕЙ ИМПУЛЬСА НАПРЯЖЕНИЯ
}

\author{
Р.А. Анохин, С.Н. Дубнюк, Н.И. Гапоненко, А.Ф. Кобец, А.И. Кравченко, О.В. Мануйленко, \\ В.Н. Решетников, А.С. Шевченко, В.А. Соченко В.Г. Свиченский, Б.В. Зайцев, А.В. Заботин, \\ В.Г. Журавлев, А.В. Журавлев
}

Описан высоковольтный импульсный модулятор, выполненный на современной полупроводниковой элементной базе. Модулятор предназначен для использования в системе питания инжектора линейного ускорителя ионов гелия. Модулятор позволяет плавно регулировать амплитуду (110...150 кВ) и длительность импульса $(0,5 \ldots 1$ мс) напряжения. Использование схемы стабилизации импульса напряжения, выполненной на основе параметрического стабилизатора с параллельным переключением нагрузки, позволило увеличить ускоренный ток пучка на выходе ускорителя в 2 раза.

\section{ВИСОКОВОЛЬТНИЙ МОДУЛЯТОР ІНЖЕКТОРА ЛІНІЙНОГО ПРИСКОРЮВАЧА ЗІ СТАБІЛІЗАЦІЕЮ ІМПУЛЬСУ НАПРУГИ}

Р.О. Анохін, С.М. Дубнюк, М.І. Гапоненко, А.П. Кобець, А.І. Кравченко, О.В. Мануйленко, В.М. Речетніков, О.С. Невченко, В.А. Соченко, В.Г. Свіченський, Б.В. Зайцев, О.В. Заботін, В.Г. Журавльов, О.В. Журавльов

Описано високовольтний імпульсний модулятор, виконаний на сучасній напівпровідниковій елементній базі. Модулятор призначений для використання в системі живлення інжектора лінійного прискорювача іонів гелію. Модулятор дозволяє плавно регулювати амплітуду $(110 \ldots 150$ кВ) і тривалість імпульсу $(0,5 \ldots 1$ мс) напруги. Використання схеми стабілізації імпульсу напруги, виконаної на основі параметричного стабілізатора 3 паралельним перемиканням навантаження, дозволило збільшити прискорений струм пучка на виході прискорювача в 2 рази. 